\section{Young Field-grown Kiwifruit Plants' Response to Early Autumn Frost Injury in Texas}

\author{
Timothy P. Hartmann ${ }^{1}$, Justin J. Scheiner ${ }^{1}$, Larry A. Stein ${ }^{2}$, \\ Andrew R. King ${ }^{1}$, and Sam E. Feagely ${ }^{3}$
}

Additional Index words. acclimation, Actinidia chinensis, Actinidia deliciosa, clonal, freeze, frost tolerance, fuzzy kiwifruit, golden kiwifruit, rootstock, seedling

Summary. Two-year-old, field-grown golden kiwifruit (Actinidia chinensis) and fuzzy kiwifruit (Actinidia deliciosa) plants were evaluated for injury following an early freeze event of $-4.1^{\circ} \mathrm{C}$ on 14 Nov. 2018 in Burleson County, TX. Plant material included seven cultivars: one seed-propagated [Sungold ${ }^{\mathrm{TM}}$ (ZESY002)] and three cutting-propagated golden kiwifruit (AU Golden Dragon, AU Golden Sunshine, CK03), and one seed-propagated (Hayward) and two cutting-propagated fuzzy kiwifruit (AU Authur and AU Fitzgerald). Observations were made 5 weeks after the frost event. Base trunk diameter (BD) and maximum trunk diameter damaged (MDD) provided a reference of plant size and crude measurement of damage intensity, as evident by presence of water-soaked necrotic and/or dehydrated tissue following the removal of a thin slice of periderm, vascular cambium, phloem, and xylem. Percent of base diameter damaged (PBDD) was calculated as MDD divided by $\mathrm{BD}$ and provided an assessment of damage, unbiased by plant size. Percent of shoot damaged (PSD) was visually evaluated as the percentage of entire shoot system exhibiting damage. In addition, presence of basal damage (DB) and basal cracking (CB) were recorded. A strong cultivar response was observed for $\mathrm{BD}, \mathrm{MDD}, \mathrm{PBDD}$, and PSD. Mean cultivar values for PSD ranged from $79 \%$ and $19 \%$ for AU Authur and Sungold ${ }^{\mathrm{TM}}$ seedlings, respectively, which represented extremes among cultivars. Fuzzy kiwifruit exhibited greater injury (PBDD, PSD, DB, and CB) as compared with golden kiwifruit cultivars. Basal damage and basal cracking proved unique to fuzzy kiwifruit, as DB ranged from $0 \%$ in Sungold ${ }^{\mathrm{TM}}$ seedlings to $100 \%$ in fuzzy kiwifruit 'AU Authur' and 'AU Fitzgerald'. In spite of having greater vigor, golden kiwifruit plants sustained less injury. Method of propagation had no effect on injury. PBDD and PSD proved to be reliable field assays for documenting injury, based on their strong correlation value $(r=0.92)$. Greater relative autumn frost tolerance of golden kiwifruit over fuzzy kiwifruit cultivars is previously unreported.

Received for publication 17 June 2020. Accepted for publication 29 Oct. 2020.

Published online 16 December 2020.

${ }^{1}$ Department of Horticultural Sciences, Texas A\&M University, 495 Horticulture Street, College Station, TX 77843

${ }^{2}$ Department of Horticultural Sciences, Texas A\&M University, P.O. Box 1849, Uvalde, TX 78802

${ }^{3}$ Department of Soil and Crop Sciences, Texas A\&M University, 370 Olsen Boulevard, College Station, TX 77843

This study represents a portion of the dissertation submitted by Timothy P. Hartmann for completion of Doctoral Degree.

Funding for this project was provided by the Texas Department of Agriculture Specialty Crops Block Grant (TDA-SCBG) Program.

Special thanks to James Spiers of Auburn University for plant material and to David Creech of Stephen F. Austin State University for collaboration in securing funding for this work. We would also like to acknowledge Robert Shropshire for his assistance with data collection.

T.P.H. is the corresponding author. E-mail: t-hartmann@ tamu.edu.

This is an open access article distributed under the CC BY-NC-ND license (https://creativecommons.org/ licenses/by-nc-nd/4.0/).

https://doi.org/10.21273/HORTTECH04670-20
G olden kiwifruit (A. chinensis) and fuzzy kiwifruit $(A$. deliciosa) are known to require distinct climatic conditions for successful production (Ferguson, 1991; Norton, 1994). For optimal production, a long growing season of 225 to $240 \mathrm{~d}$ without frost is required (Norton, 1994). Limited cold tolerance is generally considered the greatest barrier to production. Although vines can be severely damaged or killed by temperatures of $-12.2^{\circ} \mathrm{C}$ or lower (Norton, 1994), kiwifruit also have a specific requirement for winter chilling to overcome rest and produce a sufficient crop (Snelgar et al., 1997), with standard cultivars such as Hayward requiring as much as 1150 chill units (Caldwell, 1989). Studies by Caldwell (1989) and Dozier et al. (1992) reported that sites such as South Carolina in the southeastern United States that receive adequate chilling were also subject to serious, damaging freezes. Although new growth may emerge from damaged portions of the plant (Testolin and Messina, 1987), frequent severe injury to plants would limit the development of commercial production (Chat, 1995; Dozier et al., 1992), because flowers and fruit are produced on the previous year's canes (Brundell, 1975).

Although little information is available regarding cold tolerance of golden kiwifruit relative to fuzzy kiwifruit, they have unique (although often times overlapping) native ranges (Huang, 2016). Considering the broad geographic distribution and highly heterozygous nature of both species, it would be expected that relative cold tolerance between these species would vary considerably by cultivar. Kiwifruit are functionally dioecious, with segregation ratios for sex among seedlings reportedly expected to have a $1: 1$ ratio (Huang, 2016).

As a temperate or warm subtropical plant, kiwifruit is able to tolerate substantial cold, provided that they are conditioned by gradually declining temperatures (Sale and Lyford, 1990). Lu and Reiger (1990) reported that decreasing photoperiod combined with cool, nonfreezing temperatures are most conducive to acclimation, whereas mild temperatures leading up to hard and early autumn frost present the greatest risk for damage to the nonacclimated vines (Sale and Lyford, 1990). However, temperatures between -2.8 and $-6.0^{\circ} \mathrm{C}$ can cause injury to canes and even trunks, in the absence of acclimation (Blanchet, 1985; Hewett and

\begin{tabular}{llll}
\hline $\begin{array}{l}\text { Units } \\
\begin{array}{l}\text { To convert U.S. to SI, } \\
\text { multiply by }\end{array}\end{array}$ & U.S. unit & SI unit & $\begin{array}{l}\text { To convert SI to U.S., } \\
\text { multiply by }\end{array}$ \\
\hline 0.3048 & $\mathrm{ft}$ & $\mathrm{m}$ & 3.2808 \\
2.54 & inch $(\mathrm{es})$ & $\mathrm{cm}$ & 0.3937 \\
25.4 & inch $(\mathrm{es})$ & $\mathrm{mm}$ & 0.0394 \\
1 & $\mathrm{ppm}$ & $\mathrm{mg} \cdot \mathrm{kg}^{-1}$ & 1 \\
$\left({ }^{\circ} \mathrm{F}-32\right) \div 1.8$ & ${ }^{\circ} \mathrm{F}$ & ${ }^{\circ} \mathrm{C}$ & $\left({ }^{\circ} \mathrm{C} \times 1.8\right)+32$
\end{tabular}


Young, 1981; Norton, 1994), with young vines reportedly killed to the ground by autumn temperatures as warm as $-3{ }^{\circ} \mathrm{C}$ (Bullard, 1987; Krewer et al., 1986; Lu and Reiger, 1990). Such trunk damage is commonly accompanied by the development of vertical cracking of bark or "trunk-splitting" (Dozier et al., 1992; Gremminger et al., 1982; Massai et al., 1991; Sale and Lyford, 1990), which is typically restricted to the lower 10 to $15 \mathrm{~cm}$ above ground level (Dozier et al., 1992; Sale and Lyford, 1990).

The degree of damage sustained is greatly influenced by amount of acclimation the plant has received (Lawes et al., 1995; Lu and Reiger, 1990), the stage of development (Hewett and Young, 1981; Pyke et al., 1986), the intensity and duration of the frost (Pyke et al., 1986; Testolin and Messina, 1987), plant age (Pyke et al., 1986), the genetic limits of the cultivar (Dozier et al., 1992; Pyke et al., 1986), and even method of propagation (Massai et al., 1991). Although controlled environment-based experiments and associated assays offer the advantage of repeatability, field-based studies are considered most accurate and reliable $(\mathrm{Li}, 1984)$. The objective of this study was to study the response of young kiwifruit plants to an unusually early and hard autumn frost and assess the effects of species, cultivar, and propagation method.

\section{Materials and methods}

Plant material. Plant material included both clonally propagated (male and female) selections and seed-propagated material of both golden kiwifruit and fuzzy kiwifruit species (Table 1). A total of five clonally propagated cultivars were used in this study. 'AU Authur' is a clonally propagated fuzzy kiwifruit selection that was found as a chance seedling near Mobile, AL, and is used as a pollinizer for 'AU Fitzgerald'. 'CK03' ('Meteor') is a clonally propagated golden kiwifruit selection that has been widely used as a pollinizer for golden kiwifruit 'Hortl6A' (Seal et al., 2013). 'AU Golden Dragon' and 'AU Golden Sunshine' are clonally propagated pistillate selections of golden kiwifruit. 'AU Fitzgerald' is a clonally propagated female fuzzy

Table 1. Description of plant material used in the assessment of injury to seven young field-grown golden and fuzzy kiwifruit cultivars in response to an early hard autumn frost on 14 Nov. 2018 at a field trial planting near College Station, TX. Species, propagation method, sex, and other remarks defined for each cultivar/treatment.

\begin{tabular}{llll}
\hline Cultivar & \multicolumn{1}{c}{ Species } & Propagation method $^{\mathrm{z}}$ & Sex $^{\mathbf{y}}$ \\
\hline AU Authur & Fuzzy kiwifruit & Clonal & Male \\
AU Fitzgerald & Fuzzy kiwifruit & Clonal & Female \\
AU Golden Dragon & Golden kiwifruit & Clonal & Female \\
AU Golden Sunshine & Golden kiwifruit & Clonal & Female \\
CK03 (Meteor) & Golden kiwifruit & Clonal & Male \\
Hayward seedling & Fuzzy kiwifruit & Sexual (open-pollinated & Mixed \\
& & seed) & \\
Sungold & & Sexual (open-pollinated & Mixed \\
seedling & Golden kiwifruit & seed) & \\
\hline
\end{tabular}

${ }^{\mathrm{z} S e x u a l l y ~ p r o p a g a t e d ~ p l a n t s ~ w e r e ~ p r o d u c e d ~ f r o m ~ s t o r e-b o u g h t ~ f r u i t ~ o f ~ k n o w n ~ c u l t i v a r, ~ c l e a n e d, ~ s t r a t i f i e d ~ f o r ~} 4$ weeks, and sown in Mar. 2016. Clonally propagated plants were produced from softwood cuttings under mist and in June 2016

${ }^{\mathrm{y}}$ Both golden kiwifruit and fuzzy kiwifruit are dioecious. Seedlings are expected to segregate in a 1:1 female-tomale ratio.

kiwifruit selection that originated as a chance seedling of 'Hayward' near Mobile, AL, and has also performed well in central Alabama. Two seedpropagated cultivar groups were also included in the study. These include open-pollinated seedlings of Sungold $^{\text {TM }}$ ('ZESY002') golden kiwifruit and 'Hayward' fuzzy kiwifruit. Seedling plants were expected to contain both male and female individuals. Seed collected from store-bought Sungold ${ }^{\mathrm{TM}}$ and 'Hayward' fruit were cleaned and stratified for 4 weeks and sown in Mar. 2016. Clonal cultivars were propagated from softwood cuttings under mist during June 2016. All plants were transplanted into l-gal nursery containers and grown in pine bark-based soilless media under greenhouse conditions for the remainder of the season.

Field establishment and MaInTENANCE. Plantings were made during June 2017 in raised field nursery beds, which were prepared with the incorporation of 3 inches of composted pine bark (Bailey Bark Materials, Nacogdoches, TX) into the field nursery at the Texas A\&M University Horticulture Research, Teaching, and Extension Center (HORT-TREC) field laboratory located $\approx 10$ miles southwest of College Station, TX (lat. $30^{\circ} 36^{\prime} \mathrm{N}$, long. $96^{\circ} 18^{\prime} \mathrm{W}$ ) in the Brazos River bottom. Soil at the site was defined by the U.S. Department of Agriculture (USDA) National Resource Conservation Service as a Weswood silt loam (fine-silty, mixed, superactive, thermic Udifluventic Haplustepts) soil (USDA, 2005). Plants were placed on 1.5 - $\mathrm{ft}$ centers in singlerow beds that were spaced $3 \mathrm{ft}$ apart. Soil nitrogen $(\mathrm{N})$, phosphorus $(\mathrm{P})$, and potassium $(\mathrm{K})$ content were determined by and Mehlich III extraction (Mehlich, 1984) in conjunction with inductively coupled optical emission spectrometry [ICP-OES (SPECTROBLUE; SPECTRO Analytical Instruments, Kleve, Germany)], following soil sampling to a depth of 12 inches. P deficiency was corrected via sidedressing of superphosphate $[0 \mathrm{~N}-$ 7.9P-0K (American Plant Food Corp., Galena Park, TX)]. Chelated iron (Sprint 138; BASF Corp., Florham Park, NJ), manganese (Manganese Chelate 5\%; Growth Products, White Plains, NY), and zinc (Zinc Chelate 14\%; Carl Pool Products, Gladewater, TX) were applied as a drench, as needed, based on visual foliar deficiency symptoms. Plants were drip-irrigated and supplied with $200 \mathrm{mg} \cdot \mathrm{kg}^{-1} \mathrm{~N}$ using 33N-0P$0 \mathrm{~K}$ [urea/ammonium nitrate (American Plant Food Corp.)] via irrigation after establishment through late Aug. 2018 , at which point plants received irrigation only. For each plant, several shoots were trained to grow up a single 6 -ft bamboo stake during 2017. Plants were pruned back to a height of 12 inches in Jan. 2018 and trained in the same manner during the 2018 growing season.

Plant tissue nutrition was also assessed during the first week of Oct. 2018. Two youngest fully expanded leaves (whole leaves) were collected 
from each plant, hand-washed with mild phosphate-free detergent solution, double-rinsed with distilled water, dried in a forced-air oven (214330; Hotpack Corp., Philadelphia, PA) at $80^{\circ} \mathrm{C}$ for $48 \mathrm{~h}$, and sent to the Texas A\&M AgriLife Extension Soil, Water, and Forage Testing Laboratory (College Station) for testing. Total plant tissue $\mathrm{N}$ was determined by high temperature-combustion (Rapid $\mathrm{N}$ III; Elementar Americas, Ronkonkoma, NY).

Site Description. Climate at the field plot site is considered sub-humid warm-temperate with temperatures in nearby College Station, TX, ranging from $41.2^{\circ} \mathrm{F}$ (average January minimum temperature) to $96.3{ }^{\circ} \mathrm{F}$ (average August maximum temperature), with 40.06 inches of average annual precipitation. College Station historically receives an average of 274 frostfree days. The lowest and highest recorded temperatures ever recorded are -3 and $112^{\circ} \mathrm{F}$, respectively $(\mathrm{Na}-$ tional Weather Service, 2019). Winter chilling accumulation generally ranges from 600 to 700 units $(<45$ ${ }^{\circ} \mathrm{F}$ ), with the average first and last day of frost occurring on $30 \mathrm{Nov}$. and 1 Mar., respectively (Texas A\&M AgriLife Extension Service, 2019).

EXPERIMENTAL DESIgN. Experimental design consisted of a randomized complete block design with three blocks. Rows were used as blocks, with outer rows serving as borders. Seven cultivar treatments were included, with each experimental unit containing an average of five plants $(\mathrm{n}=5)$ as subsamples (range of 3 to 10$)$.

Data collection. Plant assessments of frost injury were made 19 to 22 Dec. $2018, \approx 5$ weeks after the freeze event on 14 Nov. 2018. A total of six variables were assessed to evaluate frost damage in the field (Table 2). All assessments were made visually, based on the presence of dark discolored tissue with a water-soaked appearance or based on the presence of moist necrotic tissue. A sharp knife was used to remove a thin slice $(\approx 4$ $\mathrm{cm}$ long) of bark and wood to expose the cork, phloem, vascular cambium, and xylem tissues. This was done, starting with the distal-most and smallest diameter wood and progressing downward toward the main shoot and base until no more injured tissue was observed. Several shoots were evaluated for each plant. The

Table 2. Description of six parameters used in the assessment of injury to seven young field-grown golden and fuzzy kiwifruit cultivars to an early hard autumn frost on 14 Nov. 2018 at a field trial planting near College Station, TX.

\begin{tabular}{lcl}
\hline Parameter assessed $^{\mathrm{z}}$ & Abbreviation & \multicolumn{1}{c}{ Unit } \\
\hline Base diameter & BD & Millimeters \\
Maximum diameter damaged & MDD & Millimeters \\
Percent of base diameter damaged & PBDD & Percent \\
Percent of shoot system damaged & PSD & Percent \\
Basal damage & DB & Binary (yes $=1$, no $=0$ ) \\
Basal cracking & CB & Binary (yes $=1$, no $=0$ ) \\
\hline
\end{tabular}

${ }^{\mathrm{z}}$ All assessments were made $\approx 5$ weeks after frost event. BD was measured as the trunk diameter using a digital caliper at ground level for each plant. MDD was measured using a digital caliper at the transition zone between frost-injured and healthy tissue on the largest shoot exhibiting frost injury, as evident by necrotic tissue, following exposure of cork, phloem, cambium, and xylem tissues with a sharp knife. PBDD was calculated as [PBDD = $(\mathrm{MDD} \div \mathrm{BD}) \times 100]$. PSD was visually estimated based on the prevalence of injured wood relative to healthy, uninjured wood, as evident by necrotic tissue, following exposure of cork, phloem, cambium, and xylem tissues with a sharp knife. DB was assessed by removing a thin slice of wood and bark from four sides of the trunk, starting $25 \mathrm{~cm}$ (9.8 inches) above ground level and downward to the plant base, as evident by dead phloem, vascular cambium, and in some cases primary xylem. CB was assessed by carefully inspecting for the formation of vertical cracks in the outer bark.

maximum diameter of shoot (MDD) exhibiting injury was recorded (millimeters) along with the basal trunk diameter $[\mathrm{BD}$ (millimeters) $]$ at ground level. The extent of damage to the whole shoot system was estimated in two ways: 1) percent shoot diameter damaged relative to base diameter (PBDD), which was calculated as $[\mathrm{PBDD}=(\mathrm{MDD} \div \mathrm{BD}) \times 100]$ and 2 ) percent of the entire shoot (PSD) system that was injured, which was visually estimated based on the prevalence of injured wood that was exposed, as described earlier.

The lower trunk of each plant was carefully inspected for the formation of vertical cracks in the bark. Frequency of basal cracking $(\mathrm{CB})$ was reported in a binary fashion as "yes" or "no". Young kiwifruit plants are reported to sustain freeze damage that is often confined to the basal 5 to $25 \mathrm{~cm}$ of the trunk. For this reason, a thin slice of wood and bark $(\approx 3$ to 4 $\mathrm{cm}$ long) was also removed on four sides of the trunk, starting $25 \mathrm{~cm}$ above ground level to assess for injury to the trunk. Death or damage of trunk base (DB), as evident by dead phloem, vascular cambium, and in some cases primary xylem, was reported as completely damaged $=1.0$; partially damaged (one side of base) $=0.5$; or not damaged $=0$.

Statistical analysis. All statistical analyses were performed using JMP software (version 14.0; SAS Institute, Cary, NC). BD, MDD, PBDD, and PSD were treated as continuous response variables, whereas $\mathrm{CB}$ and DB were considered nominal response variables. Mean $\mathrm{BD}, \mathrm{MDD}, \mathrm{PBDD}$, and PSD response to cultivar was analyzed using one-way analysis of variance at the 0.05 alpha level. Mean separation by cultivar was estimated using Tukey's honestly significant different test $(0.05$ alpha level). Pearson's $\chi^{2}$ test was used to compare effects of species and cultivar on nominal variables $\mathrm{DB}$ and $\mathrm{CB}$. Frequency of $\mathrm{DB}$ and $\mathrm{CB}$ within individual cultivars and between species for comparison was done based on the frequency of affected individual plants for each cultivar or species. The Student's $t$ test ( 0.05 alpha level) was used to compare the effect of propagation method (clonal and seedling) and species (golden kiwifruit and fuzzy kiwifruit) on all response variables. For species, analysis was carried out for all cultivar groups (seedlings and clonal plants) and then separately for only seedlings of each species.

Correlation strengths between response variables were estimated using the row-wise method. Principal component analysis (PCA) was performed on six variables used to assess damage and four nominal/ordinal variables: species, propagation method, and cultivar. Determination of variable retention from PCA was based on eigenvalue of 1.0 or greater for nonrotated factors. Eigenvalue score plots were used to estimate the effect of vectors on total variance. Rotational factor analysis (principal components factoring method and principal components prior communality) with orthogonal varimax and oblique promax were used to potentially reduce the number of variables by grouping those with similar characteristics. For each rotation, three 
factors were used. Factors that had a significant loading factor of $<0.30$ were considered nonsignificant.

\section{Results and discussion}

SumMary OF WeATHER Data. On the morning of 14 Nov. 2018, College Station was hit by an unusually hard frost. The recorded minimum temperature of $24.6^{\circ} \mathrm{F}\left(33^{\circ} \mathrm{F}\right.$ below average) served as the first frost of the season, effectively breaking a record low set in 1916. Weather conditions during the $60 \mathrm{~d}$ before the frost were comparatively normal in relation to average. Only $7 \mathrm{~d}$ recorded minimum temperatures below $50^{\circ} \mathrm{F}$ during the $60-\mathrm{d}$ period before the frost, with all but two of those days occurring during the week leading up to event.

Despite the generally mild temperature trend leading up to the frost, mean daily temperatures were well below $\left(11.7^{\circ} \mathrm{F}\right)$ average for the 5 $\mathrm{d}$ leading up to the frost, as a result of the passage of an earlier cold front (Fig. 1). Temperatures remained below freezing for a total of $\approx 13 \mathrm{~h}$ under clear skies with wind speeds averaging $7 \mathrm{mph}$ during this period. The dew point remained $\approx 3.1{ }^{\circ} \mathrm{F}$ below the actual air temperature at the coldest point. Mean daily temperatures continued to trend below normal for the week following the 13 to 14 Nov. frost by an average of $11.5^{\circ} \mathrm{F}$ through the $7-\mathrm{d}$ period. The remainder of Winter 2018-19 was relatively mild, with respect to frost. Winter chilling accumulation was relatively normal, with 706 and 686 units ( $<45$ and 32 to $45^{\circ} \mathrm{F}$, respectively) recorded for College Station, TX.

Plant observations. At the time formal assessments were made, frost-killed foliage had completely dried, but had not abscised. Damage to the above-ground shoot portions of plants appeared in two distinct patterns: 1) beginning from the smaller-diameter distal shoots progressing downward toward the trunk; 2 ) at the basal portion of the trunk (Fig. 2A and B). All surveyed plants were in an active state of growth at the time of the frost event, as evident by presence of new growth with expanding leaves. However, all foliage exhibited a dark water-soaked appearance, followed by rapid wilting and desiccation later in the day on 14 Nov. after temperatures warmed. Within $2 \mathrm{~d}$, knife-testing of affected wood revealed dark discolored phloem and cambial tissue. Longitudinal cracks in the bark on lower trunks became visible within 1 to 2

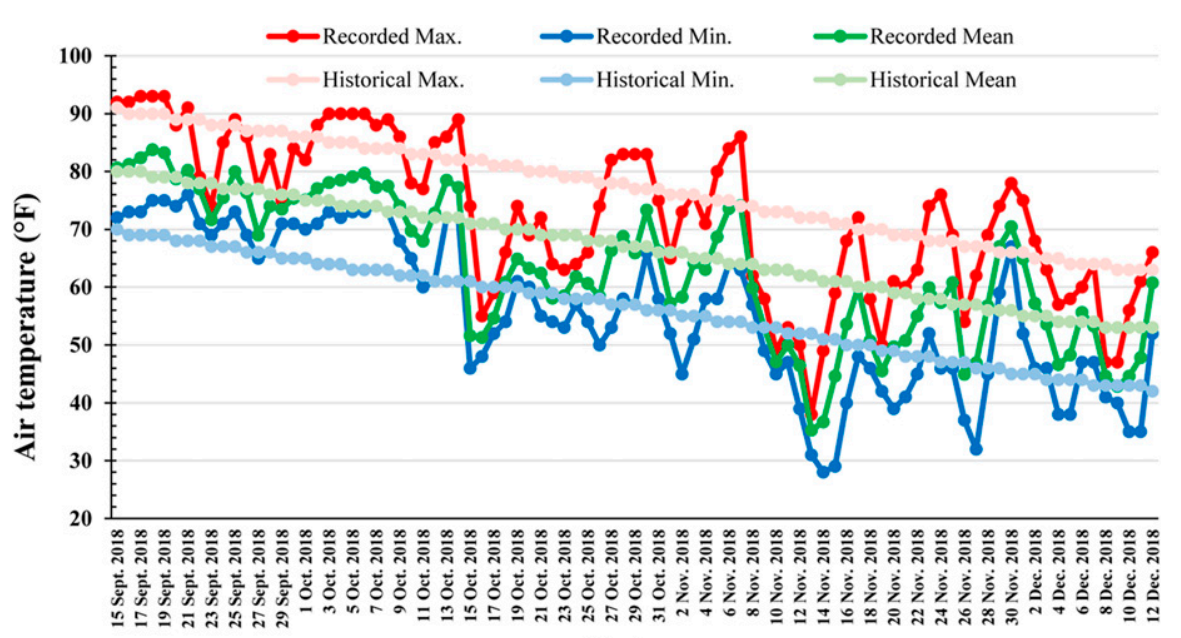

Date

Fig. 1. Daily air temperatures recorded from 15 Sept. through 12 Dec. 2018 at College Station, TX, near the field site for the frost injury study of young fieldgrown golden and fuzzy kiwifruit plants that was conducted during Winter 2018 19. Recorded daily maximum (red), recorded mean (dark green), and recorded minimum (dark blue) relative to historical maximum (pink), historical mean (light green), and historical minimum (light blue) air temperatures; 102-year record daily minimum air temperature set on 14 Nov. 2018. Historical mean temperature databased on 30-year record. Weather data from the National Weather Service (KCLL Station); historical means were based on 30-year average. Temperature data from National Weather Service $(2019) ;\left({ }^{\circ} \mathrm{F}-32\right) \div 1.8={ }^{\circ} \mathrm{C}$. weeks and continued to become more evident as the damaged and exposed phloem tissue continued to dry out.

BASE DIAMETER AND MAXIMUM DIAMETER DAMAGED. BD, which served as an estimate of plant size and baseline for quantifying injury, varied strongly among cultivars, with a range of 6.8 to $25.5 \mathrm{~mm}$ observed among individual plants. The largest group consisted of all four golden kiwifruit cultivar treatments, and the intermediate and smallest groups comprised solely of fuzzy kiwifruit (Fig. 3). Interestingly, both female cultivars (AU Golden Dragon and AU Fitzgerald) in this study produced smaller plants on average than their respective male pollinizers (CK03 and AU Authur), as supporting the assertion by Ferguson (1991) that male plants tend to be more vigorous. Golden kiwifruit plants proved to be $5.1 \mathrm{~mm}$ larger in basal diameter in this study as compared with fuzzy kiwifruit, both among clonal selections and seedlings, suggesting a clear tendency for greater vigor within the golden kiwifruit species (Fig. 4). The natural geographic range of each species might play a role in this difference, considering that golden kiwifruit tends to be found in more coastal regions and at lower elevations, whereas fuzzy kiwifruit originates in more interior locations and generally at higher elevations (Huang, 2016). The absence of a plant size response to propagation method suggests that there is no inherent difference in vigor between clonally and seedpropagated kiwifruit plants, at least within this study (Fig. 5). The same trend was noted by Hernandez et al. (1997) and Monastra and Testoni (1991), whereas Loreti et al. (1991) reported greater vigor in seedlings.

Maximum diameter of shoot damage served to provide a crude quantifiable record of shoot damage-irrespective of actual plant size. Damage was highly variable by cultivar, as evident by an observed range of 0 to $25.5 \mathrm{~mm}$ among individual plants. Based on this measurement, 'CK03' (19.0 mm) exhibited the greatest average damage and Sungold $^{\text {TM }}$ seedling $(7.3 \mathrm{~mm})$ the least (Fig. 3). Among treatments in the intermediate groups, greater damage was evident in 'AU Authur' as compared with 'AU Golden Sunshine'. For MDD, there was no significant 


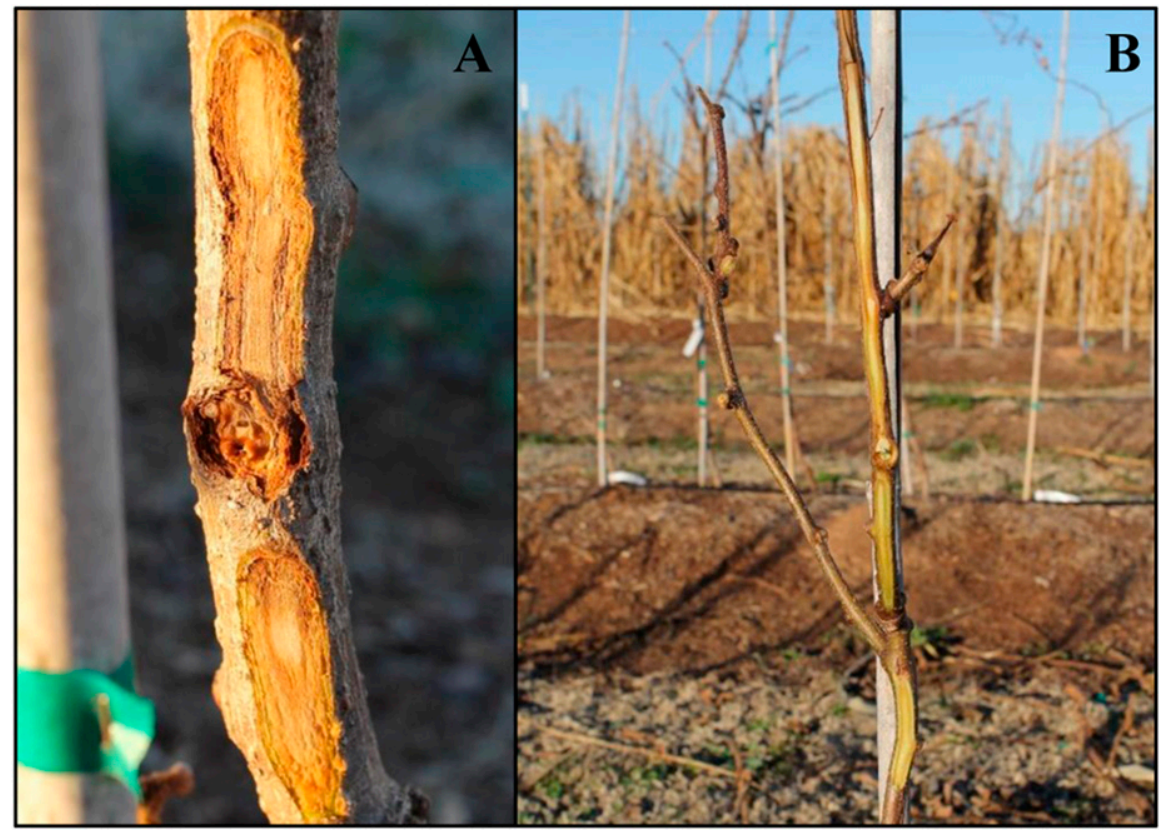

Fig. 2. Examples of injury symptoms observed in young field-grown golden and fuzzy kiwifruit plants resulting from an early hard autumn frost on 14 Nov. 2018 at a field trial planting near College Station, TX. (A) Damaged 'CK03' golden kiwifruit shoot revealed by "knife test" with dark discolored phloem, vascular cambial, and primary xylem tissue and necrotic lateral bud. (B) Primary shoot of 'Hayward' seedling fuzzy kiwifruit exhibiting basipetal injury trend with undamaged lateral buds in the apical region attempting to resume growth (right).

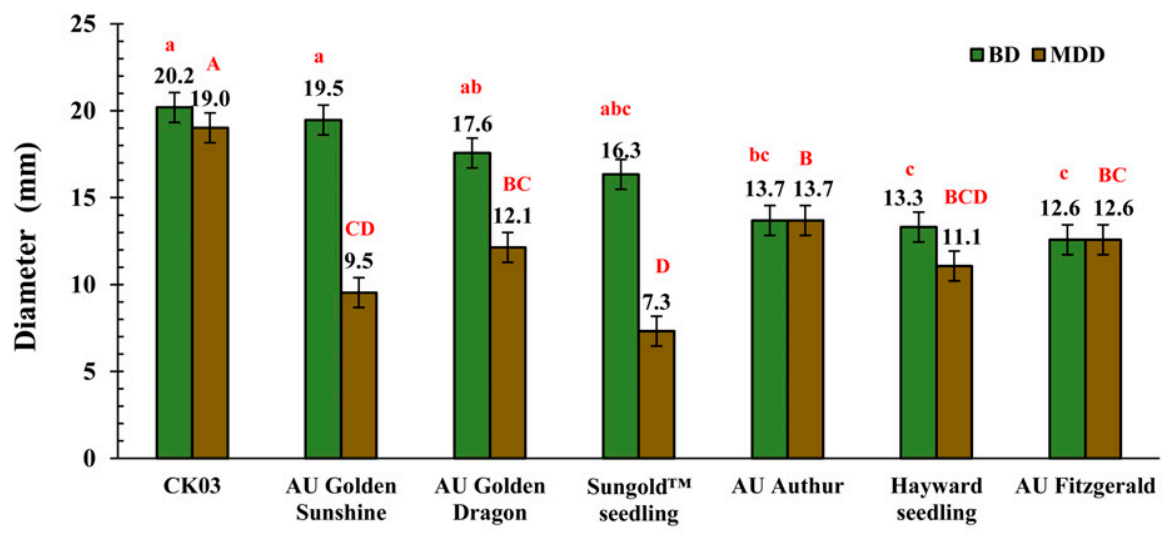

Cultivar

Fig. 3. Mean base diameter (BD) and mean maximum diameter of shoot system damaged (MDD) assessed for seven cultivars of young field-grown golden and fuzzy kiwifruit plants in response to injury resulting from an early hard autumn frost on 14 Nov. 2018 at a field trial planting near College Station, TX. BD was measured as basal trunk diameter. MDD was measured at the transition zone between frost-injured and healthy tissue on the largest shoot exhibiting frost injury (Table 2). Cultivar treatment response to $\mathrm{BD}$ and MDD was significant at $P<$ 0.001 [one-way analysis of variance $(n=5)$ ]. Treatment means $( \pm \mathrm{SE})$ connected by the same lower-case letter are not significantly different for $\mathrm{BD}$, according to Tukey's honestly significant difference $[\mathrm{HSD}(\alpha=0.05)]$. Treatment means $( \pm$ SE) connected by the same upper-case letter are not significantly different for MDD, according to Tukey's HSD $(\alpha=0.05) ; 1 \mathrm{~mm}=0.0394$ inch.

response to species, in spite of Sungold $^{\mathrm{TM}}$ seedlings exhibiting 34\% less damage (Fig. 4). Although clonal plants sustained $4.2 \mathrm{~mm}$ greater injury, in terms of MDD (Fig. 5), it should be noted that several cultivars (CK03, specifically) with the highest mean values also produced large plants.
Percent of base diameter DAMAGED AND PERCENT OF SHOOT SYSTEM DAMAgED. Percent of base diameter damaged was considered a more comprehensive measure of damage because it takes into account the diameter of shoot damage relative to the $\mathrm{BD}$. As such, relative ranking of damage among cultivar means was considerably different for PBDD as compared with MDD. 'AU Authur' and 'AU Fitzgerald' (100.0\%) exhibited significantly greater damage than 'AU Golden Dragon' (69.8\%) and still even greater injury than 'AU Golden Sunshine' (51.3\%) and Sungold $^{\mathrm{TM}}$ seedlings (19.0\%) (Fig. 6). Individually, plants varied from having $0 \%$ PBDD to $100 \%$, as $\approx 50 \%$ of surveyed plants were frozen completely to the ground $[\mathrm{PBDD}=$ $100 \%$ (data not shown)].

Percent of shoot damaged was assessed visually and accounting for plant size, but independently of PBDD. PSD estimated total percent shoot damage, whereas PBDD tended to focus only on damage to larger-diameter shoots. PSD cultivar treatment means ranged from $79 \%$ to $19 \%$ for AU Authur and Sungold ${ }^{\mathrm{TM}}$ seedling, respectively, whereas the range of $100 \%$ to $47 \%$ for $\mathrm{PBDD}$ observed between these cultivars was considerably narrower. As a result, PBBD may be a more conservative estimator of injury as compared with PSD. Still, these two assessments effectively quantified injury based on different patterns of damage. Injury to cultivars with low PSD means, such as AU Golden Sunshine (27\%) and Sungold ${ }^{\text {TM }}$ seedling (19\%), was confined primarily to smaller shoots in the middle and upper canopy regions, whereas AU Authur and AU Fitzgerald $(\mathrm{PBDD}=100 \%)$ also sustained frequency of 1.0 (100\%) basal damage, although a substantial portion of the mid to upper portions of the shoot system remained unharmed.

Among cultivars, PSD showed a trend that was nearly identical to PBDD. However, based on this measure of damage, only 'AU Authur' and 'AU Fitzgerald' sustained significantly greater injury than 'AU Golden Sunshine' and Sungold ${ }^{\mathrm{TM}}$ seedlings. PSD mean values ranged from $79.2 \%$ for 'AU Authur' to only $19 \%$ Sungold ${ }^{\mathrm{TM}}$ seedling. In fact, individual plants of these cultivars exhibited responses of $100 \%$ and $0 \%$ 


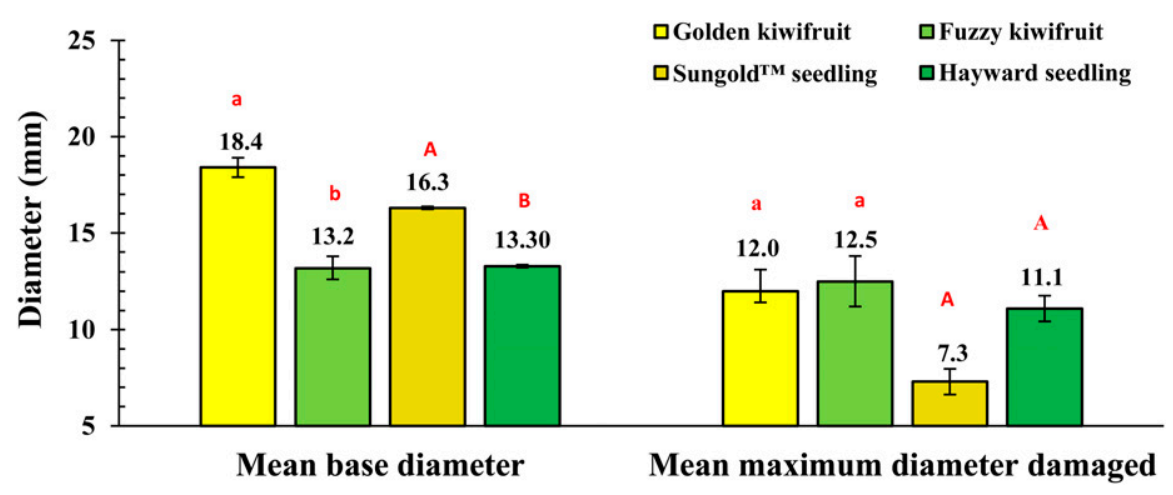

Fig. 4. Mean base diameter (BD) and maximum diameter of shoot system damaged (MDD) assessed for young field-grown plants of golden and fuzzy kiwifruit species and their respective seedlings in response to injury resulting from an early hard autumn frost on 14 Nov. 2018 at a field trial planting near College Station, TX. MDD response to species and species seedling treatment was nonsignificant. BD was measured as basal trunk diameter. MDD was measured at the transition zone between frost-injured and healthy tissue on the largest shoot exhibiting frost injury (Table 2 ). BD response to species and species seedling treatment (Sungold ${ }^{\mathrm{TM}}$ seedling and 'Hayward' seedling) was significant at $P<0.001$ and $P=$ 0.001 , respectively. Species treatment means $( \pm S E)$ connected by the same lowercase letter are not significantly different for BD and MDD, according to Student's $t$ test $(\alpha=0.05)$. Species seedling treatment means $( \pm S E)$ connected by the same upper-case letter are not significantly different for BD and MDD; $1 \mathrm{~mm}=\mathbf{0 . 0 3 9 4}$ inch.

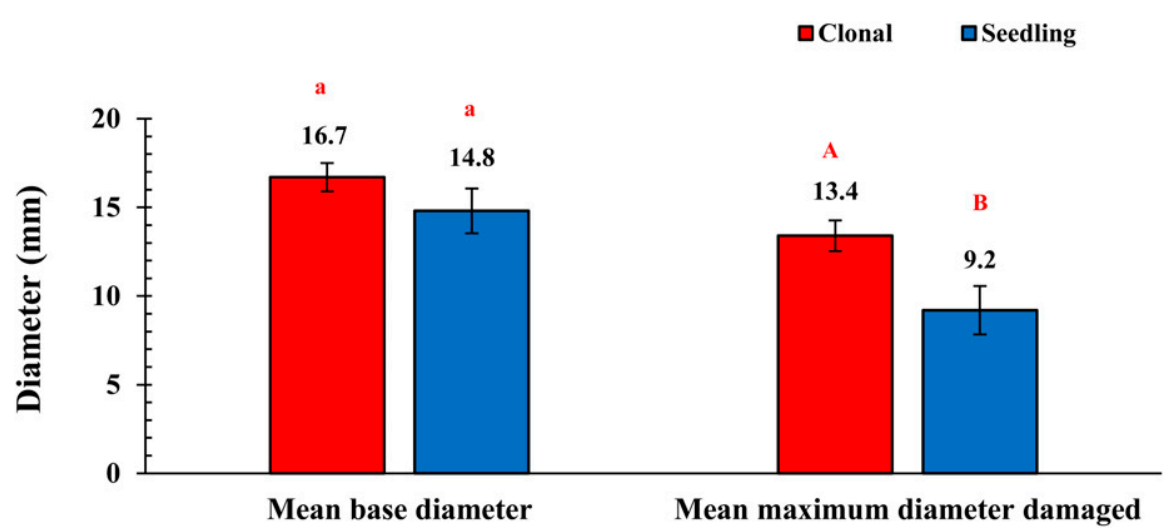

Fig. 5. Mean base diameter (BD) and mean maximum diameter of shoot system damaged (PBDD) assessed for young field-grown plants of golden and fuzzy kiwifruit species in response to injury resulting from an early hard autumn frost on 14 Nov. 2018 at a field trial planting near College Station, TX. BD was measured as basal trunk diameter. Maximum diameter damaged (MDD) was measured at the transition zone between frost-injured and healthy tissue on the largest shoot exhibiting frost injury (Table 2 ). MDD response to propagation method was significant at $P=0.018$. Propagation method treatment means $( \pm S E)$ connected by the same lower-case letter are not significantly different for $\mathrm{BD}$, according to Student's $t$ test $(\alpha=0.05)$. Propagation method treatment means $( \pm \mathrm{SE})$ connected by the same upper-case letter are not significantly different for MDD, according to Student's $t$ test $(\alpha=0.05) ; 1 \mathrm{~mm}=0.0394$ inch.

shoot damage, respectively. Species had an effect on both PBDD and PSD. On average, fuzzy kiwifruit reported $29 \%$ greater PBDD, as compared with golden kiwifruit plants and $31.6 \%$ greater PSD, respectively. These differences were even greater for PBDD (36.4\%) and PSD (35.4\%) in the case of seedlings for each species (Fig. 7). Neither PBDD nor PSD showed response to propagation method. Thus, there is no indication that cutting-grown plants are inherently less frost tolerant than seedlings, once plant size is accounted for (data not shown).

BASAL DAMAgE AND BASAL CRACKING. As previously mentioned, frost injury generally followed two patterns: basipetal progression and prevalence of damage to basal stem regions. Damage to trunk bases and subsequent cracking appeared to occur somewhat independently from general damage to the remainder of the shoot system (Fig. 8A and B). In fact, some of the affected plants had relatively little damage to the smaller shoots in the middle to upper canopy region. Some of these shoots responded with budbreak (especially in apical nodes) a few weeks after the frost, suggesting that they had not yet entered endodormancy. As one might expect, this growth was ultimately killed by subsequent frost events.

Vertical cracks in the bark of the basal portion of the trunk on some plants became evident within a few weeks and continued to increase in size and number as time went on (Fig. $9 \mathrm{~A}$ and $\mathrm{B})$. Basal cracking (CB) appeared to trend strongly with basal damage (DB), which was readily visible when formal assessments were made. Both $\mathrm{CB}\left(\chi^{2} P<0.001\right)$ and $\mathrm{DB}\left(\chi^{2} P=0.001\right)$ were strongly associated with base diameter (BD) (data not shown).

Both incidence of $\mathrm{DB}$ and $\mathrm{CB}$ were highly responsive to cultivar. 'AU Authur', 'AU Fitzgerald', 'CK03', and 'Hayward' seedlings experienced the highest incidence of $\mathrm{DB}$, with $100 \%$ of individual 'AU Authur' and 'AU Fitzgerald' plants exhibiting death of phloem, vascular, cambium, and primary xylem. Average DB for 'AU Golden Sunshine' and Sungold ${ }^{\mathrm{TM}}$ seedling was significantly lower, with $0 \%$ of individual Sungold ${ }^{\mathrm{TM}}$ seedling plants showing signs of DB (data not shown). Cultivar response to $\mathrm{CB}$ followed a very similar trend, as the group with the highest average $\mathrm{CB}$ was composed solely of fuzzy kiwifruit cultivars. As a species, fuzzy kiwifruit cultivars exhibited an average $\mathrm{CB}$ frequency of 0.79 , as compared with that of 0.11 for golden kiwifruit cultivars, with the same trend holding true for seedlings of each species (Fig. 10). Eighty-two percent of individual plants in this species sustained basal damage and $79 \%$ had visible cracking, compared with $35 \%$ and $11 \%$, 


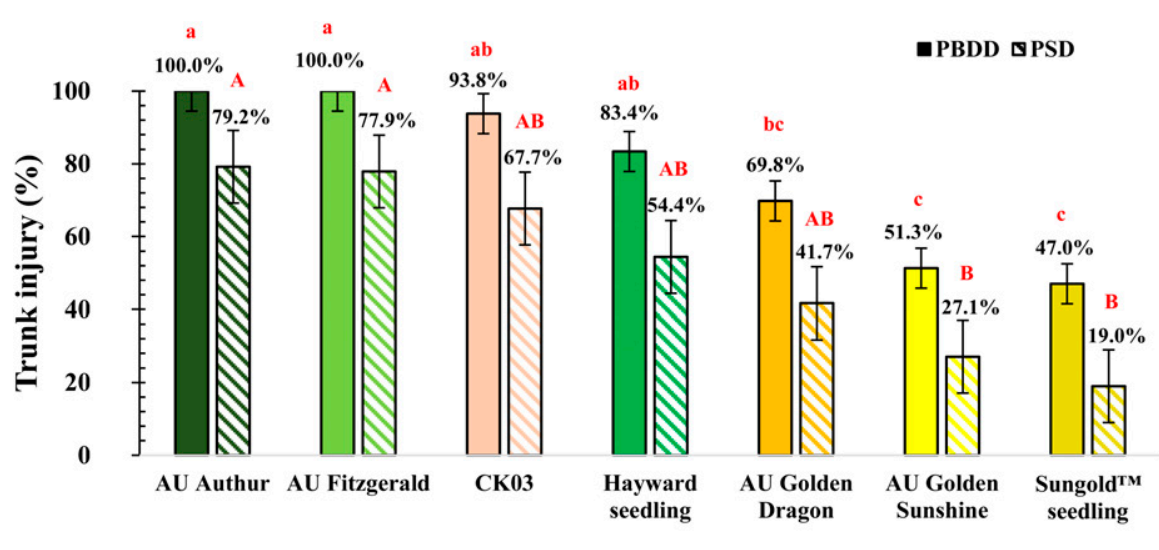

Cultivar

Fig. 6. Mean percent of base diameter damaged (PBDD) and mean percent of shoot system damaged (PSD) assessed for seven cultivars of young field-grown golden and fuzzy kiwifruit plants in response to injury resulting from an early hard autumn frost on 14 Nov. 2018 at a field trial planting near College Station, TX. PBDD was calculated as $[\mathrm{PBDD}=(\mathrm{MDD} \div \mathrm{BD}) \times 100]$. PSD was assessed based on the prevalence of injured wood relative to healthy, uninjured wood (Table 2 ). Cultivar treatment response to PBDD and PSD was significant at $P<0.001$ and $P=0.005$, respectively [one-way analysis of variance $(n=5)$ ]. Treatment means $( \pm S E)$ connected by the same lower-case letter are not significantly different for PBDD, according to Tukey's honestly significant difference $[\operatorname{HSD}(\alpha=0.05)]$. Treatment means $( \pm S E)$ connected by the same upper-case letter are not significantly different for PSD according to Tukey's HSD $(\alpha=0.05)$.

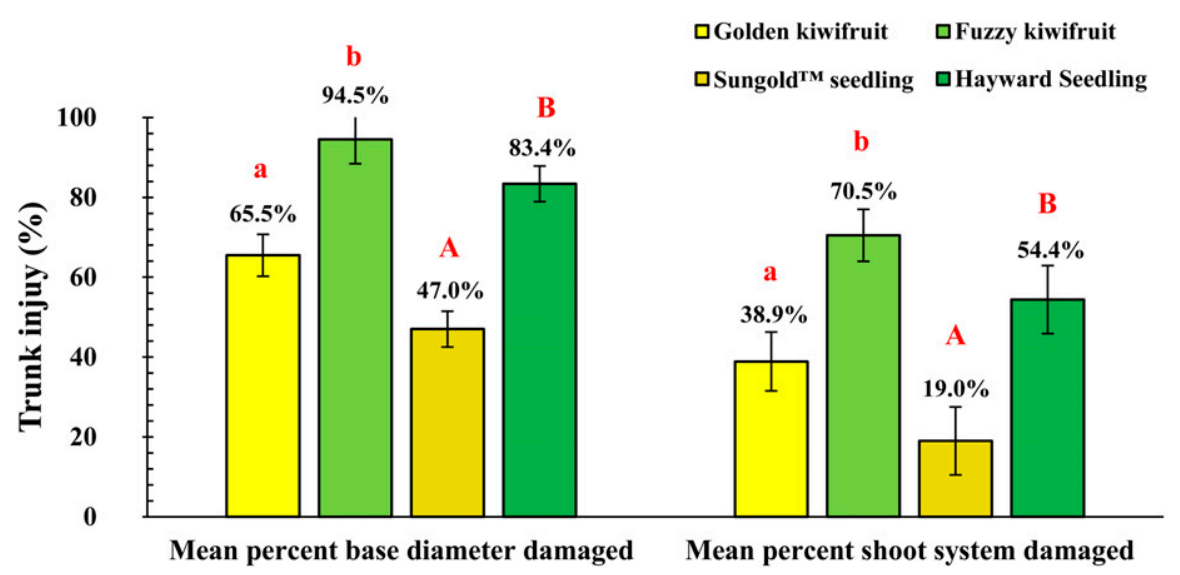

Fig. 7. Mean percent of base diameter damaged (PBDD) and mean percent of shoot system damaged (PSD) assessed for young field-grown plants of golden and fuzzy kiwifruit species and their respective seedlings in response to injury resulting from an early hard autumn frost on 14 Nov. 2018 at a field trial planting near College Station, TX. PBDD calculated as $[\mathrm{PBDD}=(\mathrm{MDD} \div \mathrm{BD}) \times 100]$. PSD was assessed based on prevalence of injured wood relative to healthy, uninjured wood (Table 2). PBDD response to species and species seedling treatment (Sungold ${ }^{\mathrm{TM}}$ seedling and 'Hayward' seedling) was significant at $P=0.002$ and $P=$ 0.03 , respectively. Species treatment means $( \pm S E)$ connected by the same lowercase letter are not significantly different for PBDD and PSD, according to Student's $t$ test $(\alpha=0.05)$. Species seedling treatment means $( \pm \mathrm{SE})$ connected by the same upper-case letter are not significantly different for PBDD and PSD, according to Student's $t$ test $(\alpha=0.05)$.

respectively, for all golden kiwifruit plants (data not shown).

Observations suggest that greater tendency for cracking in this species might be related to differences in the structure of its periderm and phloem. Fuzzy kiwifruit (particularly 'Hayward' and 'Bruno' seedlings) is widely used as a rootstock for both fuzzy and golden kiwifruit. The tendency of young fuzzy kiwifruit plants to sustain basal injury presents a major challenge to this species as a rootstock in the southeastern United States. Propagation method had no effect on either DB or CB (data not shown).

Principal component analysis AND CORRelations. Principal component analysis provided additional insight into the comprehensive relationships among the six variables assessed. PCA 1 and PCA 2 had Eigenvalues of 4.2 and 1.3 , respectively, and together accounted for $\approx 92.5 \%$ of the total variance associated with all six variables. PCA 3-6 collectively accounted for a total of only $7.5 \%$ of the total variance and had Eigenvalues less than 1.0, therefore were not further considered. The strong partial contributions of PBDD, DB, and PSD $(22.7 \%, 22.1 \%$, and $21.1 \%$, respectively) suggest that these variables were important in partitioning the variance explained by PCA 1 , whereas $C B$, MDD, and $\mathrm{BD}$ were also influential. For PCA 2, only BD (49.7\%) and MDD (40.3\%) appeared to contribute strongly, whereas CB and PSD appeared to play more minor roles. Rotational factor analysis (principal components factoring method and principal components prior communality) with orthogonal varimax and oblique promax were used to potentially reduce the number of variables by grouping those with similar characteristics. However, the analysis failed to suggest the removal of any factors, therefore all six were retained (data not shown).

The positive association of MDD, PBDD, and PSD with both PCA 1 and PCA 2 (Fig. 11A), along with strongly positive correlations between these variables (Table 3), suggest that these three variables had similar and positive effects on frost damage, particularly MDD. However, for MDD, its implications are very much limited, unless plant size (BD) is taken into account. PBDD and PSD had very similar characteristics, as evident by the high and positive correlation strength $(r=0.92)$ between these two variables. Together, they accounted for $43.8 \%$ of the variance explained by PCA 1 . Treatment means for ' $\mathrm{CK} 03$ ' and clonal propagation were also positively associated with PCA 1 and PCA 2, reaffirming the high degree of injury that was observed for these treatments, particularly with respect to MDD (Fig. 11B). 'CK03' 


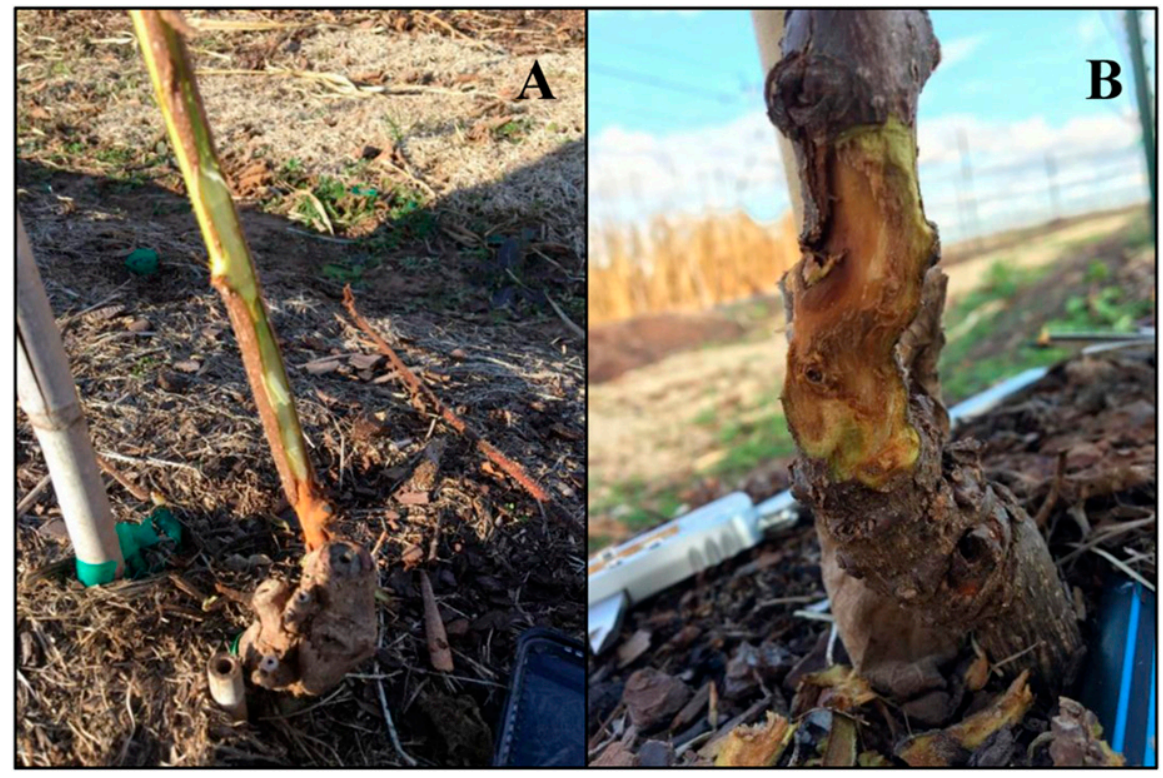

Fig. 8. Examples of injury symptoms observed in young field-grown golden and fuzzy kiwifruit resulting from an early hard autumn frost on 14 Nov. 2018 at a field trial planting near College Station, TX. (A) 'Hayward' seedling fuzzy kiwifruit with damage, as evident by sloughing bark and dark discolored primary xylem restricted to basal portion of primary shoot with apparent healthy shoot tissue above. (B) Injury to basal region of ' $\mathrm{CK03'}$ ' golden kiwifruit plant, as evident by dark discolored phloem, cambial, and primary xylem tissue.

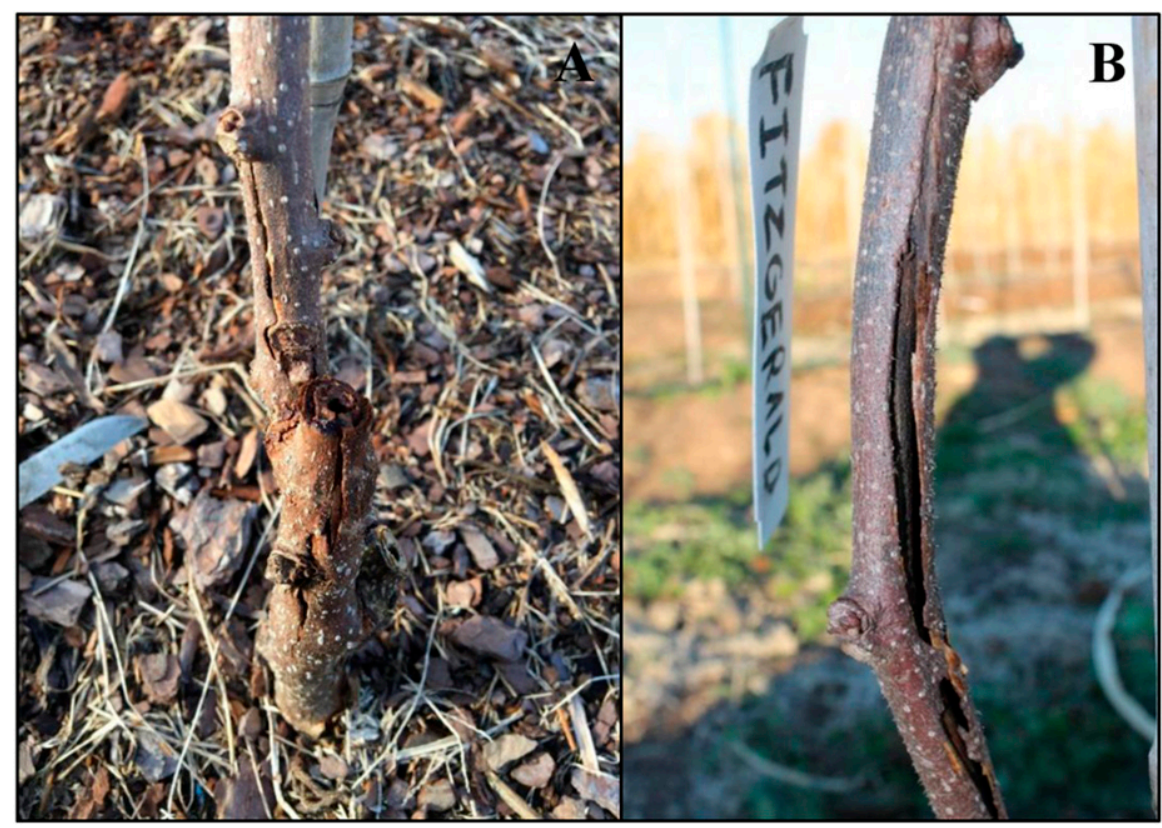

Fig. 9. Examples of injury symptoms observed in young field-grown golden and fuzzy kiwifruit resulting from an early hard autumn frost on 14 Nov. 2018 at a field trial planting near College Station, TX. (A) 'AU Authur' fuzzy kiwifruit plant exhibiting extensive vertical cracking of basal bark. (B) 'AU Fitzgerald' fuzzy kiwifruit plant with vertical cracking extending up primary shoot.

ranked highest for MDD, third for PBDD and PSD, among cultivars. On average, clonal plants had higher MDD damage and noticeably higher PBDD and PSD values, as compared with seedlings.

BD accounted for only $6.9 \%$ of the variance explained by PCA 1 , but
$49.7 \%$ for PCA 2. The positive and negative associations with PCA 2 and PCA 1 (respectively) and negative correlations with PBDD, $\mathrm{CB}$, and $\mathrm{DB}$, support the earlier assertion that vigor was not a contributor to frost injury in this study. Cultivar means for AU Golden Sunshine, AU Golden Dragon, and species mean for golden kiwifruit showed similar associations. Indeed, 'AU Golden Sunshine' and 'AU Golden Dragon' ranked second and third (respectively) among cultivars for $\mathrm{BD}$, whereas golden kiwifruit (all cultivars) as a species, resulted in $39 \%$ larger than fuzzy kiwifruit plants, on average. Conversely, 'AU Golden Sunshine' and 'AU Golden Dragon' ranked fifth and fourth (respectively) for MDD, whereas golden kiwifruit sustained slightly more (not significantly) damage $(12.0 \mathrm{~mm})$ than fuzzy kiwifruit plants $(12.5 \mathrm{~mm})$, on average. Finally, 'AU Golden Sunshine' and 'AU Golden Dragon' ranked sixth and fourth, respectively for PBDD and sixth and fifth, respectively for PSD. Golden kiwifruit plants (all cultivars) exhibited 28.0\% and $31.6 \%$ lower PBDD and PSD (respectively), as compared with fuzzy kiwifruit on average.

None of the six variables used were negatively associated with both PCA 1 and PCA 2. However, both treatment means for Sungold ${ }^{\mathrm{TM}}$ seedlings and seedling propagation method were, reaffirming that these treatments were less severely affected by MDD, PBDD, and PSD, than 'Hayward' seedling and clonal propagation method, respectively, as previously discussed.

Only CB was positively associated with PCA 1 , but negatively associated with PCA 2, whereas DB was also positively correlated with PCA 1 , but had no apparent relationship with PCA 2. This was not unanticipated, considering that $\mathrm{CB}$ was negatively correlated with $\mathrm{BD}$, but not significantly correlated with MDD, and positively and strongly correlated with PBDD and PSD. DB followed the same trend, although it was positively and strongly correlated with MDD. CB accounted for $16.6 \%$ of the variance explained by PCA $\mathrm{l}$ and $7.8 \%$ for PCA 2, whereas DB accounted for $22.1 \%$ of the variance explained by PCA 1 and $0 \%$ for PCA 2. Fuzzy kiwifruit as a species, along with all three cultivars within that 


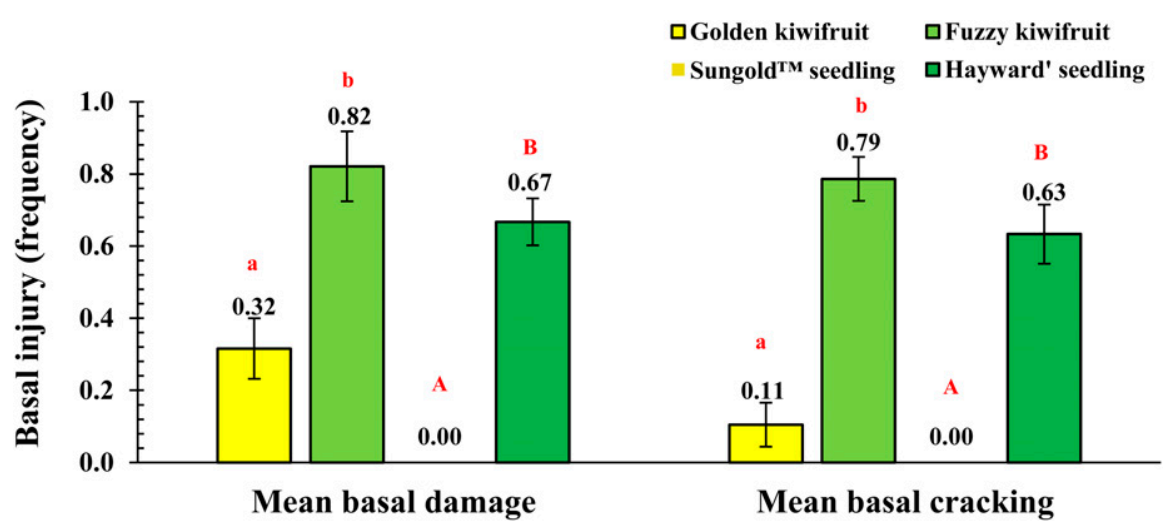

Fig. 10. Mean incidence of basal damage (DB) and basal cracking (CB) assessed for young field-grown plants of golden and fuzzy kiwifruit species in response to injury resulting from an early hard autumn frost on 14 Nov. 2018 at a field trial planting near College Station, TX. DB was assessed based on the appearance of dead phloem, vascular cambium, and primary xylem present in lower $25 \mathrm{~cm}(9.8$ inches) of trunk. CB was assessed based on the formation of vertical cracks in the outer bark (Table 2). DB response to species and species seedling treatment (Sungold ${ }^{\mathrm{TM}}$ seedling and 'Hayward' seedling) was significant at $P<0.001$ and $P=$ 0.02 , respectively. $\mathrm{CB}$ response to species and species seedling treatment was significant at $P=0.005$ and $P=0.03$, respectively. Species treatment means $( \pm \mathrm{SE}$ ) connected by the same lower-case letter are not significantly different for DB and $\mathrm{CB}$, according to Student's $t$ test $(\alpha=0.05)$. Species seedling treatment means $( \pm$ $\mathrm{SE})$ connected by the same upper-case letter are not significantly different for DB and $\mathrm{CB}$, according to Student's $t$ test $(\alpha=0.05)$.

Table 3. Correlation coefficients among six parameters used to assess injury to seven cultivar treatments for the assessment of injury to young field-grown golden and green kiwifruit plants following an early hard frost on 14 Nov. 2018 at a field trial planting near College Station, TX.

\begin{tabular}{lcccccc}
\hline $\begin{array}{l}\text { Parameter } \\
\text { assessed }^{z}\end{array}$ & BD & MDD & PBDD & CB & DB & PSD \\
\hline BD & 1.00 & $0.21 \mathrm{NS}^{\mathrm{y}}$ & $-0.47^{*}$ & $-0.63^{* *}$ & $-0.53^{*}$ & $-0.41 \mathrm{NS}$ \\
MDD & & 1.00 & $0.75^{* * *}$ & $0.33 \mathrm{NS}$ & $0.63^{* *}$ & $0.70^{* * *}$ \\
PBDD & & & 1.00 & $0.76^{* * *}$ & $0.94^{* * *}$ & $0.92^{* * *}$ \\
BC & & & & 1.00 & $0.77^{* * *}$ & $0.71^{* * *}$ \\
DB & & & & & 1.00 & $0.90^{* * *}$ \\
PSD & & & & & & 1.00 \\
\hline
\end{tabular}

${ }^{\mathrm{z}}$ All assessments were made $\approx 5$ weeks after frost event. Base diameter $(\mathrm{BD})$ was measured as basal trunk diameter. Maximum diameter damaged (MDD) was measured at the transition zone between frost-injured and healthy tissue on the largest shoot exhibiting frost injury. Percent of base diameter damaged (PBDD) was calculated as [PBDD = $(\mathrm{MDD} \div \mathrm{BD}) \times 100]$. Basal cracking $(\mathrm{CB})$ was assessed based on the formation of vertical cracks in the outer bark. Basal damage (DB) was assessed based on the appearance of dead phloem, vascular cambium, and primary xylem present in lower $25 \mathrm{~cm}$ (9.8 inches) of trunk. Percent of shoot system damaged (PSD) was assessed as prevalence of injured wood relative to healthy, uninjured wood (Table 2 ).

${ }^{y}$ Correlation probabilities were considered as Ns, ${ }^{*},{ }^{*}$, or *** (nonsignificant or significant at $P \geq 0.05, P<0.05$ $P<0.01$, or $P<0.001$, respectively). Correlations were estimated using the row-wise method.

species (AU Authur, AU Fitzgerald, and Hayward seedling), showed a strong association with basal cracking and (to a lesser degree) basal damage and negative association with basal diameter. As expected, these cultivars were the smallest in size, whereas fuzzy kiwifruit, as a species, were $\approx 28 \%$ smaller than golden kiwifruit plants on average. Propensity for basal damage, and especially basal cracking, proved to be traits that were more unique to fuzzy kiwifruit plants, as 'AU Authur', 'AU Fitzgerald', and 'Hayward' seedling ranked first, second, and fourth (respectively) for DB and first, second, and third (respectively) for CB. As a species, fuzzy kiwifruit was $256 \%$ more likely to exhibit basal damage and $718 \%$ more likely to show cracking, as compared with golden kiwifruit cultivars.

OTHER CONSIDERATIONS. Golden kiwifruit cultivars, which were also significantly larger, proved to be less prone to frost injury, in comparison with fuzzy kiwifruit cultivars. Chat (1995) observed greater injury (necrosis length) in larger fuzzy kiwifruit plants; however, when expressed as a percentage of plant height, these differences were no longer significant. However, the previous experiment studied the effects of injury as imposed by artificial freezing during midwinter, using dormant plants and did not include the golden kiwifruit species. In the current experiment, a positive correlation $\left(P=0.04, r^{2}=0.49\right)$ was observed between plant size (BD) and injury (MDD) within the fuzzy kiwifruit plants studied. However, no such association was observed between MDD and PSD or PBDD (where plant size is considered), as noted by Chat [1995 (data not shown)]. Improved frost tolerance within the fuzzy kiwifruit species is reportedly associated with a smaller amount of larger-diameter xylem vessels (Massai et al., 1991), increased phloem-glucose and fructose, elevated abscisic acid, and reduced shoot tissue $\mathrm{N}$ concentrations ( $\mathrm{Kim}$ and Kim, 1986). The specific mechanism that might confer improved frost tolerance to the golden kiwifruit species is not known; however, it seems unlikely that this is simply a result of greater vigor, as fuzzy kiwifruit plants of comparable size exhibited notably greater injury as compared with golden kiwifruit, particularly in the case of basal injury.

Male 'CK03' plants had higher PBDD and PSD as compared with their female counterpart 'AU Golden Dragon' on average, whereas male 'AU Authur' and female 'AU Fitzgerald' plants averaged nearly equal damage, based on PBDD and PSD. This pattern of greater damage to male cultivars (also seen for $\mathrm{CB}$ and $\mathrm{DB}$ ) is potentially due to the reported tendency of male plants to remain in active growth later in the season (Ferguson, 1991) and resulting diminished frost tolerance (Pyke et al., 1986; Strik, 2005). However, all plants were observed to be in active growth at time of the frost.

It is also noteworthy that a substantial number of 'AU Golden Dragon', and to a lesser degree, 'AU Golden Sunshine' lacked the typical frozen phloem, but showed a thin dark discolored line between the phloem and primary xylem. Such damage was 

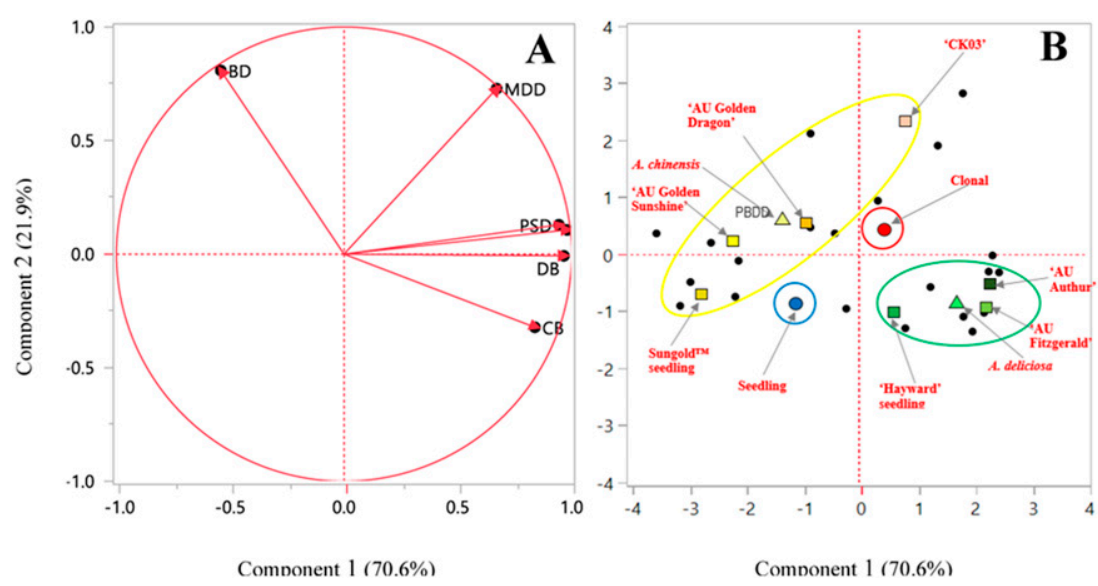

Fig. 11. Principal components assessed for seven cultivar treatments of young field-grown golden and fuzzy kiwifruit plants in response to injury resulting from an early hard autumn frost on 14 Nov. 2018 at a field trial planting near College Station, TX. (A) Summary plot for PCA 1 and PCA 2 showing relationships associated with all six response variables used. Arrows that are in close proximity of one another indicated that the associated variables are closely associated for each vector. (B) Score plot showing means for cultivar treatment, propagation method, and species. Clustering indicated by means for golden kiwifruit and respective cultivars in yellow, fuzzy kiwifruit and respective cultivars in green, seedling in blue, and clonal propagation means in red. Base diameter (BD) was measured as basal trunk diameter. Maximum diameter damaged (MDD) was measured at the transition zone between frost-injured and healthy tissue on the largest shoot exhibiting frost injury. Percent of base diameter damaged (PBDD) was calculated as $[\mathrm{PBDD}=(\mathrm{MDD} \div \mathrm{BD}) \times 100]$. Basal cracking $(\mathrm{CB})$ was assessed based on the formation of vertical cracks in the outer bark. Basal damage (DB) was assessed based on the appearance of dead phloem, vascular cambium, and primary xylem present in lower $25 \mathrm{~cm}$ (9.8 inches) of trunk. Percent of shoot system damaged (PSD) was assessed based on the prevalence of injured wood relative to healthy, uninjured wood (Table 2).

accounted for when considering MDD, PBDD, and PSD. Plants displaying these unique symptoms initially resumed shoot growth, but ultimately wilted and died in late spring. This was likely due to their inability to develop new xylem tissue as a result of the damaged or destroyed vascular cambium.

Nearly $100 \%$ of the plants that were observed ultimately survived, as those with little damage to the shoot system resumed growth in a normal fashion from shoot buds, whereas plants that were severely damaged or frozen to the ground were able to recover and produce vigorous new shoots from the crown or via root suckers.

High $\mathrm{N}$ concentration in shoot tissue during late season has long been implicated in the reduction of frost tolerance in fruit trees (Raese, 1997), including kiwifruit (Kim and Kim, 1986). Although tissue analysis of nutritional status was not sampled at the time of the frost, the same cultivars in adjacent rows, which were irrigated and fertilized in the same manner, were sampled during the first week of October. Whole leaf tissue analysis of this material reported that total $\mathrm{N}$ concentration was $2.89 \%$ at that time, which would be considered slightly above normal (Clark et al., 1986; Smith et al., 1987). Analyses did not reveal significant differences among cultivars in the nearby rows (data not shown). Soil testing of these adjacent rows in Feb. $2019(\approx 3$ months after the frost) revealed that the average nitrate- $\mathrm{N}$ concentration of $2.44 \mathrm{mg} \cdot \mathrm{kg}^{-1}$ measured in the top $15 \mathrm{~cm}$ of the soil at that time was below optimal, relative to recommendations from the Texas A\&M AgriLife Extension Soil, Water, and Forage Testing Laboratory (data not shown).

The objective of this study was to document the response of young plants to early autumn frost injury. The fuzzy kiwifruit species, particularly cultivars AU Authur and AU Fitzgerald, were more susceptible, whereas golden kiwifruit, and most notably Sungold ${ }^{\mathrm{TM}}$ seedling sustained less damage, in spite of the latter species exhibiting greater vigor. Such differences in frost tolerance between these species have not been reported elsewhere to date. Fuzzy kiwifruit plants specifically showed a greater propensity for basal damage and basal cracking-a factor that could potentially limit this species' suitability for rootstock use. Frost tolerance was not significantly different between clonally propagated plants and seedlings in this experiment. Frost injury, particularly to young plants with little cold acclimation, likely presents the single-greatest challenge to establishment of commercial kiwifruit plantings in Texas. However, it has been widely observed that the plant's tolerance improves greatly with age (Dozier et al., 1992; Lawes et al., 1995; Lu and Reiger, 1990). Successful establishment in Texas will likely require frost protection of young plants or selection of a location with milder winter temperatures, assuming winter chilling requirements can be satisfied.

\section{Literature cited}

Blanchet, P. 1985. Frost damage on kiwifruit (Actinidia chinensis Pl.), the risks of the French orchard. Fruit Growing 370:43-48.

Brundell, D.J. 1975. Flower development of the chinese gooseberry (Actinidia chinensis Planch.). N. Z. J. Bot. 13:473-483, doi: 10.1080/0028825X.1975.10430339.

Bullard, A.J. 1987. Actinidia chinensisTrials and tribulations. Pomona 10:65-69.

Caldwell, J. 1989. Kiwifruit performance in South Carolina and effect of winter chilling. Proc. Alabama Fruit Veg. Growers Assoc. 10:127-129.

Chat, J. 1995. Cold hardiness within the genus Actinidia. HortScience 30:329332, doi: 10.21273/HORTSCI.30.2.329.

Clark, C.J., G.S. Smith, M. Prasad, and I.S. Conforth. 1986. Kiwifruit, p. 23-25. In: Fertilizer recommendations for horticultural crops grown in New Zealand. Ministry Agr. Fish., Wellington, New Zealand.

Dozier, W.A., Jr., A.W. Caylor, D.G. Himelrick, and A.A. Powell. 1992. Cold protection of kiwifruit plants with trunk wraps and mircrosprinkler irrigation. HortScience 27:977-979, doi: 10.21273/ HORTSCI.27 .9.977.

Ferguson, A.R. 1991. Kiwifruit (Actinidia). Acta Hort. 290:603-656, doi: 10.17660/ActaHortic.1991.290.14. 
Gremminger, U., A. Husistein, and A. Aeppli. 1982. Reaction of young Actinidia chinensis plants to frost. Schweiz. Z. Obst- Weinbau 118:110-115.

Hernandez, D., M. Belen, M. Ara, J.C. García Rubio, and J. Berrios. 1997. Performance of kiwifruit plant material propagated by different methods. Acta Hort. 444:155-162, doi: 10.17660/ ActaHortic.1997.444.22.

Hewett, E.W. and K. Young. 1981. Critical freeze damage temperatures of flower buds of kiwifruit (Actinidia chinensis Planch.). N. Z. J. Agr. Res. 24:7375, doi: 10.1080/00288233.1981. 10420873 .

Huang, H. 2016. Kiwifruit: The genus Actinidia. Academic Press, London, UK.

Krewer, G., P. Bertrand, S. Meyers, and D. Horton. 1986. Kiwi cold injury, other problems beset southeastern plantings. Fruits $7(5): 12-15$.

Kim, H.Y. and K.R. Kim. 1986. Relationship between organic compound contents and freezing tolerance in kiwifruit plant. Res. Rept. Rural Dev. Admin. Hort. 28:95 (Abstr.).

Lawes, G.S., S.T. Cheong, and H. Varela-Alvarez. 1995. The effect of freezing temperatures on buds and stem cuttings of Actinidia species. Scientia Hort. 61:1-12, doi: 10.1016/03044238(94)00732-U.

Li, P.H. 1984. Subzero temperature stress physiology of herbaceous plants. Hort. Rev. 6:373-416.

Lu, S. and M. Reiger. 1990. Cold acclimation of young kiwifruit vines under artificial hardening conditions. HortScience 25:1628-1630, doi: 10.21273/ HORTSCI.25.12.1628.
Loreti, F., D. Piccotino, C. Xiloyannis, and G. Baroni. 1991. Effect of propagation technique on vegetative growth and fruiting in kiwifruit. Acta Hort. 297:183191, doi: 10.17660/ActaHortic.1992. 297.23.

Massai, R., D. Piccotino, G. Baroni, and C. Xiloyannis. 1991. Responses to frost in kiwifruit propagated by different techniques. Acta Hort 297:237-246, doi: 10.17660/ActaHortic.1992.297.31.

Mehlich, A. 1984. Mehlich 3 soil test extractant: A modification of Mehlich 2 extractant. Commun. Soil Sci. Plant Anal. 15:1409-1416, doi: 10.1080/ 00103628409367568 .

Monastra, F. and A. Testoni. 1991. Horticultural performance and quality characteristics of fruit from kiwifruit plants (cv. Hayward) obtained by in-vitro propagation, but cuttings and by grafting. Acta Hort. 297:197-204, doi: 10.17660/ ActaHortic.1992.297.25.

National Weather Service. 2019. College Station climate data. College Station normals/means/extremes - November. 28 Oct. 2019. <https://www.weather. gov/hgx/climate_cll_normals_nov>.

Norton, M.V. 1994. Site selection and vineyard development, p. 18-24. In: J.K. Hasey, R.S. Johnson, J.A. Grant, and W.O. Reil (eds.). Kiwifruit growing and handling. ANR Publ., Univ. California, Oakland.

Pyke, N.B., C.J. Stanley, and I.J. Warrington. 1986. Kiwifruit: Frost tolerance of plants in controlled frost conditions. N. Z. J. Expt. Agr. 14:443-447, doi: $10.1080 / 03015521.1986 .10423063$.

Raese, T.J. 1997. Cold tolerance, yield, and fruit quality of ' $d$ 'Anjou' pears influenced by nitrogen fertilizer rates and time of appli- cation. J. Plant Nutr. 20:1007-1025, doi: $10.1080 / 01904169709365313$.

Sale, P.R. and P.B. Lyford. 1990. Cultural, management and harvesting practices for kiwifruit in New Zealand, p. 247-296. In: I.J. Warrington and G.C. Weston (eds.). Kiwifruit: Science and management. N. Z. Soc. Hort. Sci., Auckland.

Seal, A.G., J.K. Dunn, and Y.L. Jia. 2013. Pollen parent effects on fruit attributes of diploid Actinidia chinensis 'Hort 16A' kiwifruit. N. Z. J. Crop Hort. Sci. 41:219-229, doi: 10.1080/01140671. 2013.803130 .

Smith, G.S., C.J. Asher, and C.J. Clark. 1987. Kiwifruit nutrition, diagnosis and disorders. Agpress Communications, Wellington, New Zealand.

Snelgar, W.P., P.J. Manson, and H.G. McPherson. 1997. Evaluating winter chilling of kiwifruit using excised canes. J. Hort. Sci. 72:305-315, doi: 10.1080/ 14620316.1997 .11515517$.

Strik, B. 2005. Growing kiwifruit. 20 Nov. 2019. <https://catalog.extension. oregonstate.edu/sites/catalog/files/ project/pdf/pnw507.pdf $>$.

Testolin, R. and R. Messina. 1987. Winter cold tolerance of kiwifruit. A survey after winter frost injury in northern Italy. N. Z. J. Expt. Agr. 15:501-504, doi: 10.1080/ 03015521.1987 .10425604$.

Texas A\&M AgriLife Extension Service. 2019. Extension education in Brazos County. 5 Nov. 2019. <https://brazos. agrilife.org/brazos-county-information/>.

U.S. Department of Agriculture. 2005. Soil survey. Web soil survey-Soil survey of Burleson County, Texas. 14 Nov. 2019. <https://websoilsurvey.sc.egov. usda.gov/App/WebSoilSurvey.aspx>. 